How to Cite: Kozhanova, A.M., Temirgaziyev, B.S., Zhanarbek, A., Tuleuov, B.I., Seilkhanov, T.M., \& Adekenov, S.M. (2021). Synthesis of a hydrophilic derivative of ecdysterone and development of its water-soluble form. Bulletin of the University of Karaganda - Chemistry, 104(4), 138-148. https://doi.org/10.31489/2021Ch4/138-148

\author{
A.M. Kozhanova ${ }^{1}$, B.S. Temirgaziyev ${ }^{1}$, A. Zhanarbek $^{1}$, \\ B.I. Tuleuov", T.M. Seilkhanov", S.M. Adekenov ${ }^{1}$ \\ ${ }^{1}$ JSC "International Research and Production Holding "Phytochemistry", Karaganda, Kazakhstan; \\ ${ }^{2}$ Sh.Ualikhanov Kokshetau University, Kokshetau, Kazakhstan \\ (*Corresponding author's e-mail: alhss@mail.ru)
}

\title{
Synthesis of a hydrophilic derivative of ecdysterone and development of its water-soluble form
}

\begin{abstract}
The article presents materials on the isolation of ecdysterone substance from medicinal plant raw materials Silene wolgensis (Hornem.) Bess. ex. Spreng (Volga smolyovka). For the first time, the optimization of the method for ecdysterone substance obtaining from the aboveground part of the superconcentrator of phytoecdysteroids of the Silene wolgensis was carried out and based on it a pilot industrial regulation for the isolation of ecdysterone and an encapsulated water-soluble form were developed. It was found, that the interaction of the substrate molecule and the clathrate forms a substance that can dissolve in water and other more polar solvents, thereby solving the problem of bioavailability of the main hydrophobic drug. The method developed for producing the substance ecdysterone and its water-soluble encapsulated with $\beta$-cyclodextrin form was implemented into production at the Karaganda pharmaceutical plant. NMR studies of changes in the chemical shifts of protons of substrates and receptors illustrated that ecdysterone interacts with $\beta$-cyclodextrin to form supramolecular inclusion complexes with stoichiometric composition of 1:1.
\end{abstract}

Keywords: ecdysterone, optimization of isolation, Silene wolgensis, $\beta$-cyclodextrin, encapsulation, water solubility, NMR, supramolecular complexes.

\section{Introduction}

Ecdysteroids (ecdysones or polyoxysteroids) regulate the molting processes of insects and crustaceans [1]. Additionally, they are also isolated from plant sources [2,3]. To date, more than 500 ecdysteroids are known, among which ecdysterone (20-hydroxyecdysone or 20E) is found in plants in large quantities.

In modern conditions, the problem of developing new drugs and biologically active food supplements containing minor components of phytoecdysteroids is becoming paramount to correct the body's adaptive reactions under stress, exposure to unfavorable technogenic and environmental factors, and high physical and emotional stress. Ecdysteroids have a wide spectrum of biological activity, are non-toxic and do not possess androgenic properties.

Ecdysteroids are found in plants, as a rule, in trace and minor amounts $-0.001-0.1 \%$, but there are also superproducer species containing up to $3.0 \%$ [4]. Phytochemical methods for the isolation of phytoecdysteroids and ecdysteroid preparations are usually traditional. For their production, such basic methods are used as grinding of raw materials, extraction, separation of solid and liquid phases, evaporation of the extract, isolation and purification of the target product [5].

The main problem in the development and creation of phytopreparations based on secondary plant metabolites is their water solubility and bioavailability. The rate and degree of bioavailability of a pharmaceutically active substrate directly depends on its water solubility and, therefore, on the ability of the drug to penetrate through obstacles to the intended target organ. However, it should be noted that along with the high and diverse biological activity and low toxicity of many natural compounds, the issues of water solubility of phytopreparations based on them, in most cases remain open. The water solubility of the substance and drugs can be increased by grinding them to nanoparticles, microemulsions, solid dispersions, or by extrusion. An alternative method to increase the solubility of phytopreparations is to obtain water-soluble cyclodextrin inclusion complexes (CIC) with many lipophilic poorly soluble compounds [6]. The main distinguishing feature of cyclodextrins (CD) is their ability to hydrophobic binding of the "guest" molecule in its cavity (encapsulation) in an aqueous medium.

A promising source of raw materials for producing the substance of ecdysterone is a plant of the genus Silene L. of the Caryophyllaceae family. This genus includes about 500 species, 62 of which grows in Kazakhstan (12 endemic species) in almost all floristic regions [7-9]. Currently, Silene wolgensis (Hornem.) 
Bess. ex. Spreng (Caryophyllaceae Juss. family), widespread in Central Kazakhstan, attracts special attention as another type of super-concentrator $(1.76 \%)$, as well as an alternative and promising industrially significant source of biologically active substances, primarily 20E [10].

The aim of this work is to obtain a water-soluble bioactive supramolecular complex based on 20 -hydroxyecdysone and its commercially available clathrate with $\beta$-cyclodextrin in a stoichiometric ratio of $1: 1$, followed by the subsequent development of a technology for the production of a substance for pharmaceutical purposes. One of the important tasks in the production of medicinal substances is standardization, thus, using the physicochemical parameters of the study, a number of works were conducted on which criteria for the inclusion complex of $20 \mathrm{E}$ with $\beta-\mathrm{CD}$ were set, on the basis of which emphasis will be placed in the production of a water-soluble adaptogen in industrial scales.

The physicochemical properties and structural features of the obtained water-soluble complex of ecdysterone with $\beta$-CD were studied applying modern physicochemical methods, namely HPLC, UV-, IR-, ${ }^{1} \mathrm{H}$ and ${ }^{13} \mathrm{C}$ NMR spectroscopy, on the basis of which data on complex formation are presented.

\section{Experimental}

$\beta$-Cyclodextrin (99\%) produced by Fluka was used in this work.

${ }^{1} \mathrm{H}$ and ${ }^{13} \mathrm{C}$ NMR spectra were recorded by the spectrometer Jeol JNM-ECA 400 (399.78 and $100.53 \mathrm{MHz}$ on nuclei ${ }^{1} \mathrm{H}$ and ${ }^{13} \mathrm{C}$, respectively) in solutions of DMSO- $\mathrm{d}_{6} \mathrm{CDCl}_{3}$ and $\mathrm{D}_{2} \mathrm{O}$ at room temperature. Chemical shifts were measured relative to the residual signals of the protons or carbon atoms of the solvent.

The melting points of the isolated and obtained samples were determined on a Boetus instrument. IR spectra were recorded on an Avatar 360 ESP spectrometer in $\mathrm{KBr}$ pellets. UV absorption spectra were recorded on an Agilent Technologies "CARY 60 UV-Vis" spectrometer.

The purity of the isolated compound was controlled by thin layer chromatography (TLC) on Sorbfil plates using a chloroform-ethanol 60:40 system, as well as by HPLC (purity $97.85 \%$ and higher).

Quantitative analysis of studied samples was carried out by high-pressure reversed-phase HPLC on a Hewlett Packard Agilent 1100 Series instrument in isocratic mode under the following conditions:

- analytical column filled with Zorbax SB-C ${ }_{18}$ sorbent, $4.6 * 150 \mathrm{~mm}$, with a particle size of 5 microns;

- mobile phase composition: $10 \%$ isopropyl alcohol;

- detection at a wavelength of $254 \mathrm{~nm}$;

- column temperature - room temperature;

- the speed of the mobile phase $-0.75 \mathrm{ml} / \mathrm{min}$;

- the volume of the injected sample $-20 \mu$ l.

The processing data was carried out using the ChemStation software.

The aerial part of Silene wolgensis raw material was collected in the Bukhar-Zhyrau region, in vicinity of village of Kyzyl-Kaiyn, Karaganda region in the flowering phase.

Extraction of the aerial part (leaves, buds, stems) of the crushed air-dry raw material of Silene wolgensis with a mass of $1.0 \mathrm{~kg}$ was carried out four times with 10 liters of $96 \%$ ethanol by heating on ERSND-1 extractor at the boiling point of the solvent for 1-1.5 hours. The extract was cooled, decanted, and evaporated on a rotary evaporator at a temperature not exceeding $50{ }^{\circ} \mathrm{C}$. After that 0.21 of ethanol was added to the resulting thick brown syrupy mass. Next, the resulting ethanol extract was treated with a mixture of petroleum ether and ethyl acetate in a ratio of 2:1 (0.4:0.2 1) in order to remove non-polar components, the remaining water-soluble part was extracted with isobutanol $(0.61)$, resulting in a thick extract. Isobutanol extracts were combined, then distilled off to dryness under vacuum. Sum of ecdysteroids $(86.5 \mathrm{~g})$ with related substances in the form of a thick green syrupy mass was obtained. The presence of ecdysterone was established by TLC and qualitative analysis. By repeated column chromatography on $\mathrm{Al}_{2} \mathrm{O}_{3}\left(\mathrm{I}^{\text {th }}\right.$ degree of activity according to Brockmann, sorbent weight $1.6 \mathrm{~kg}$ ) and elution of the column with a mixture of chloroform-ethanol (60:40), a fraction (1.0 g) was isolated on the basis of TLC ("Sorbfil"), physicochemical constants and spectral data. It was characterized as a chromatographically individual substance - ecdysterone.

The inclusion complexes of ecdysterone with $\beta$-cyclodextrin were obtained by the interaction of equimolar amounts of $20 \mathrm{E}$ and $\mathrm{CD}$ solutions. $113 \mathrm{mg} \mathrm{CD}(0.1 \mathrm{mmol})$ dissolved in $4 \mathrm{ml}$ of distilled water was added to $50 \mathrm{mg}(0.1 \mathrm{mmol})$ of $20 \mathrm{E}$ dissolved in $3 \mathrm{ml}$ of absolute ethanol. The solution was stirred using a magnetic stirrer at $50{ }^{\circ} \mathrm{C}$ for 8 hours. The formed precipitate was filtered off, washed with ethanol and dried at $40^{\circ} \mathrm{C}$. The $20 \mathrm{E}-\beta-\mathrm{CD}$ inclusion complexes were obtained in the form of white powders. In a similar way, 
inclusion complexes 1:2 were obtained. $226 \mathrm{mg} \beta$-CD $(0.2 \mathrm{mmol})$ were dissolved in $4 \mathrm{ml}$ of distilled water and added to $0.05 \mathrm{~g}(0.1 \mathrm{mmol})$ of $20 \mathrm{E}$ dissolved in $3 \mathrm{ml}$ of absolute ethanol.

\section{Results and Discussion}

In this regard, the optimization of the technology for producing ecdysterone was carried out in order to increase the yield. In particular, reextraction of a thick total alcoholic extract (the sum of substances extracted with $96 \%$ ethanol by maceration with solvent boiling followed by distillation of the extractant in vacuum to obtain a thick essence) using petroleum ether (extraction gasoline) was used to remove lipophilic components.

On the basis of the described optimized technology, a pilot industrial regulation for the isolation of ecdysterone was developed, the technological scheme for production of which includes the stage of preparation of materials (preparation of the extractant and processing of raw materials), 7 main stages (Fig. 1): preparation of raw materials, extractant; obtaining of thick extract of Silene wolgensis after extraction with ethanol; treatment of thick extract of Silene wolgensis; chromatographic separation on aluminum oxide; recrystallization of native ecdysterone; obtaining a water-soluble form of ecdysterone; packaging and labeling of the water-soluble form of ecdysterone.

The superconcentrator plant Silene wolgensis, characterized by a high yield of ecdysterone $(1.76 \%)$, exceeding its content in Serratula coronata L. $(1.5 \%)$, the plant basis of the domestic adaptogenic preparation "Ecdiphyt", is a promising and alternative species $[10,11]$.

Therefore, the aim of this work is to optimize the extraction of $20 \mathrm{E}$ isolation from this plant, collected in the Karaganda region, for its further use as an industrially available and alternative plant source. The influence of a number of technological factors (concentration of the selective extractant, temperature and time) on the quantitative extraction of $20 \mathrm{E}$ from the aerial parts and roots of the plant under study was also investigated in order to develop optimal conditions and carry out effective extraction of silene wolgensis.

A herb, crushed to $8 \mathrm{~mm}$ and a GMP-compliant extractant were applied to determine the optimal degree of extraction of ecdysterone from plant raw materials. The ecdysterone content was determined within 3,24 and 48 hours, at extraction temperatures of $20^{\circ}$ and $78^{\circ} \mathrm{C}$. The obtained results are presented in Table 1.

Table 1

\section{Results of the study of the dynamics of the extraction of silene wolgensis raw materials depending on technological factors}

\begin{tabular}{|l|c|c|c|c|c|}
\hline \multicolumn{1}{|c|}{ Extraction } & $\begin{array}{c}\text { part of a } \\
\text { plant }\end{array}$ & $\begin{array}{c}\text { grinding degree } \\
\text { of raw materi- } \\
\text { als, mm }\end{array}$ & $\begin{array}{c}\text { Extraction tem- } \\
\text { perature, }{ }^{\circ} \mathrm{C}\end{array}$ & $\begin{array}{c}\text { Extraction time, } \\
\text { hour }\end{array}$ & $\begin{array}{c}\text { The quantitative } \\
\text { content of } \\
\text { ecdysterone, } \%\end{array}$ \\
\hline Water-ethanol (70\%) & aerial part & before 8 & 20 & 24 & 0.3 \\
\hline Water-ethanol (50\%) & aerial part & before 8 & 20 & 24 & 0.26 \\
\hline Ethanol (96.2\%) & aerial part & before 8 & 20 & 24 & 1.7 \\
\hline Ethanol (96.2\%) & aerial part & before 8 & 78 & 3 & $\mathbf{5 . 2 4}$ \\
\hline Ethanol (96.2\%) in percolator & aerial part & before 8 & 20 & 48 & 1.0 \\
\hline Water-ethanol (70 \%) & root & before 8 & 80 & 3 & $\mathbf{5 . 2 4}$ \\
\hline
\end{tabular}

It was experimentally established that ethyl alcohol is the main selective extractant providing the quantitative extraction of $20 \mathrm{E}$ from silene wolgensis.

During extraction under different temperature and times conditions with other identical parameters, it was identified that an increase in temperature as one of the main factors (extractions 3 and 4 at $20^{\circ} \mathrm{C}$ and $78^{\circ} \mathrm{C}$ ) does not significantly affect the yield of $20 \mathrm{E}$.

Further search for optimal conditions for the extraction of silene wolgensis led to the conclusion that the increase in the yield of $20 \mathrm{E}$ is mainly influenced by the change in the concentration of the extractant.

It should be also noted that the complex processing of plant raw materials as a renewable material is one of the priority approaches in the rational use and chemical study of plants in terms of obtaining practically valuable substances.

Table 1 illustrates that when the aerial parts are extracted using $96.2 \%$ ethanol, and the roots with $70 \%$ ethyl alcohol, the yield of 20E from this plant is $5.24 \%$ and $5.24 \%$, respectively. 


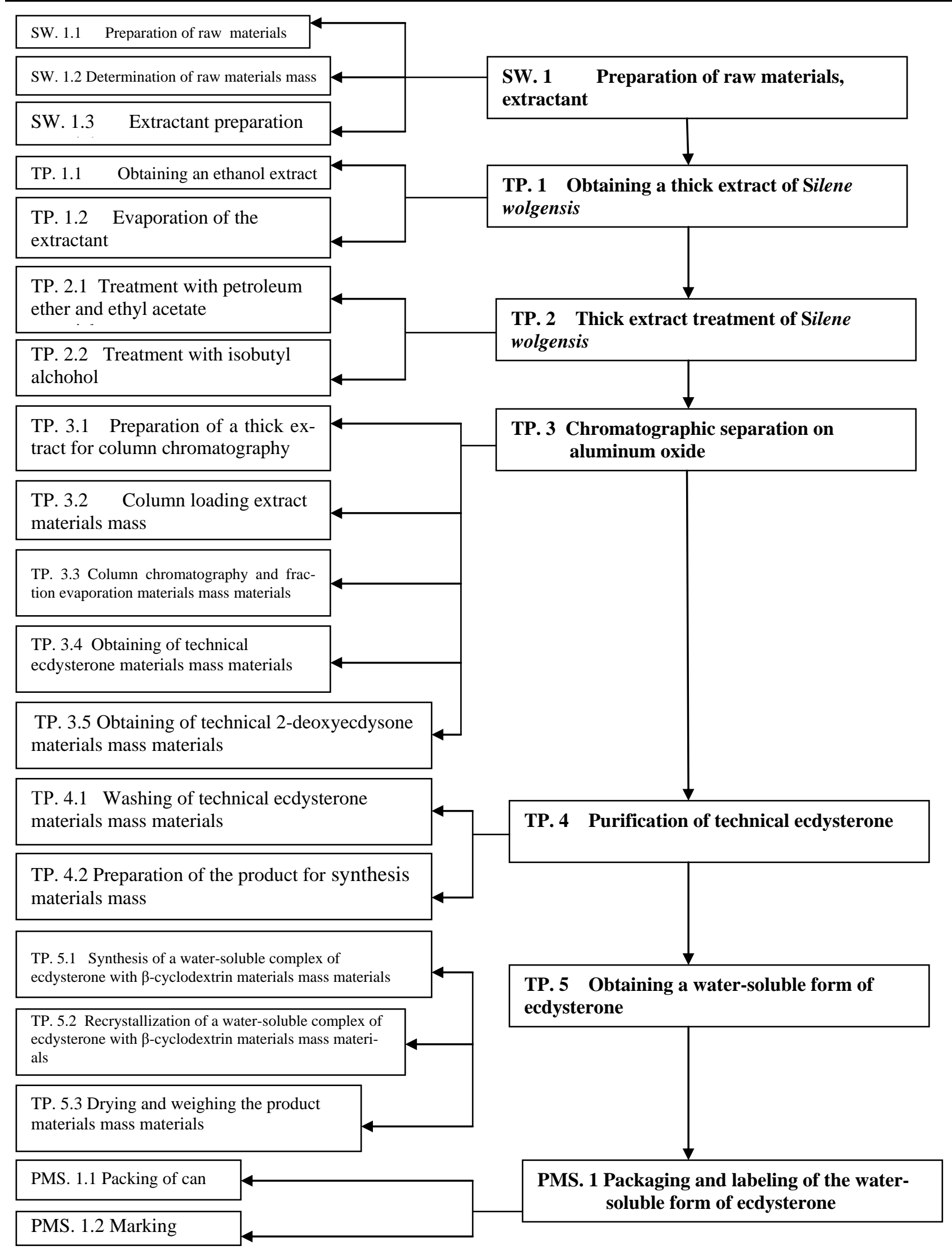

Figure 1. Technological scheme for the production of a water-soluble form of ecdysterone

As a result of the research, effective, express, and economical in terms of hardware execution conditions for the release of $20 \mathrm{E}$ were developed, using an extractant that meets GMP standards form industrially significant raw materials Silene wolgensis. 
On the basis of the results of one-factor experiments, the above factors and intervals of variation (concentration of the extractant, duration of the process, extraction temperature, degree of grinding of raw materials) were selected. The result of the application is the first developed experimental industrial regulations for the isolation of ecdysterone and the production of a water-soluble form on its basis [12-16].

As result of the work conducted to optimize the extraction of bioactive steroid compounds and column chromatography of the ethanol extract Silene wolgensis, the main phytosteroid ecdysterone $2 \beta, 3 \beta, 14 \alpha, 20 \mathrm{R}, 22 \mathrm{R}, 25$-hexahydroxy-5 $\beta(\mathrm{H})$-cholest-7-en-6-one) $\mathrm{C}_{27} \mathrm{H}_{44} \mathrm{O}_{7}$ was obtained as a white odorless powder with a purity of $98 \%$ according to HPLC. In order to establish the basic data on the physicochemical constants characteristic of ecdysterone, the following results were obtained: M.p. $236-238{ }^{\circ} \mathrm{C}$ (ethyl acetatemethanol); $[\alpha]^{20}{ }_{D}+66.0^{\circ}\left(1.0\right.$, methanol); IR (KBr) $v_{\max }, \mathrm{cm}^{-1}: 3450,2950,1652,1450,1390,1060,880$; UV spectrum (EtOH), $\lambda_{\max }, \mathrm{nm}: 243$ ( $\log \varepsilon$ 4.10). The substance is soluble in ethanol, dioxane, insoluble in water, ethyl acetate and chloroform. According to the data of primary analyzes, all available results completely coincide with the target compound ecdysterone, which is confirmed by the literature data [17].

The finished product is also a substance of a water-soluble form of ecdysterone; it is a supramolecular inclusion complex with $\beta$-cyclodextrin, obtained according to the scheme in Figure 2 and representing an odorless white powder with a basic substance content of at least $98 \%$.

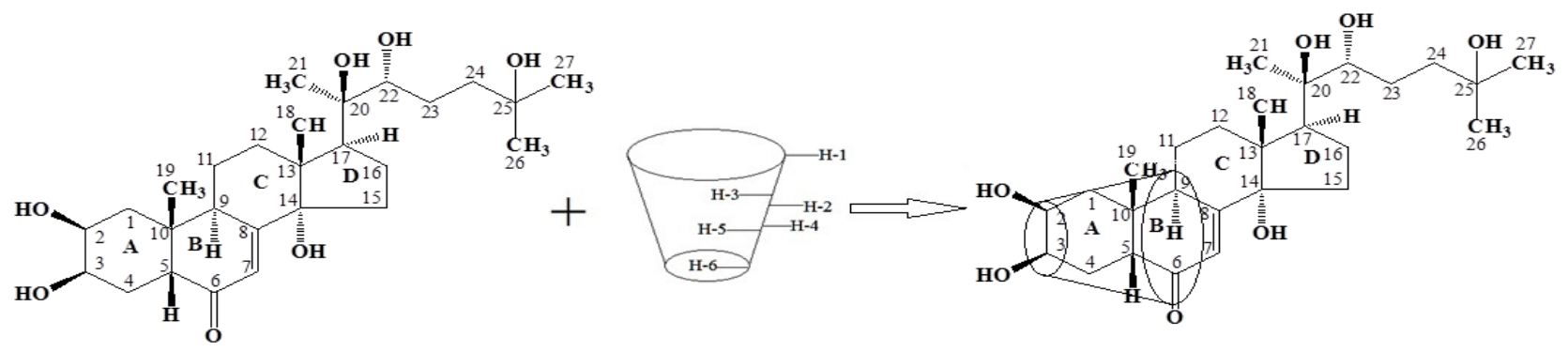

Figure 2. Scheme of the ecdysterone molecule entry into the $\beta$-cyclodextrin cavity

The possibility of creating nanocapsulated complexes of a biologically active component helps not only to increase the solubility and physicochemical stability of the substrate, but also to improve its bioavailability and local tolerance.

Thus, to establish the type of the formed inclusion complex of ecdysterone with $\beta$-cyclodextrin, the values of chemical shifts of ${ }^{1} \mathrm{H}$ of the substrate and receptors in the free state and in the composition of the supramolecule were studied (Table 2). Ecdysterone is poorly soluble in water, and its spectra are difficult to record in deuterated water. Upon complexation of $20 \mathrm{E}$ with $\beta-\mathrm{CD}$, supramolecular complexes are formed, which have a relatively high solubility in water compared to the initial 20E. Therefore, to confirm the water solubility of the complexes, NMR spectra were obtained in water. In Table 2, the first two columns demonstrate the 20E NMR spectra in deuterated chloroform and DMSO. 20E dissolves in these solvents, and can be identified by NMR spectra. The 20E NMR data in chloroform and DMSO presented in columns 1 and 2 of the table were applied to correctly identify the $20 \mathrm{E}$ spectra in the supramolecular complex. The 20E NMR signals slightly decrease in the supramolecular complex. Comparative data on changes in the chemical shifts of protons in the inner sphere are presented for free $\beta-\mathrm{CD}-\mathrm{n}$ and its complex with 20E, obtained in deuterated water.

The chemical shifts of $\beta$-CD in water are well-known and were not presented by us in Table 2 .

The main results on the structure of complexes of $20 \mathrm{E}$ with $\beta-\mathrm{CD}$ were obtained from ROESY spectra recorded in deuterated water. Based on the tabulated data, it can be noted that the protons of the inner sphere of cyclodextrin, H-3 and H-5, experience the greatest shift.

One of our goals is to characterize and disclose more detailed information on the molecular geometry of complexes of $20 \mathrm{E}$ with $\beta$-CD. First, we tried to fully decipher the signals and reveal the intermolecular interactions between 20E and CD using 2D ROESY NMR experiments.

Full assignment of ${ }^{1} \mathrm{H}$ and ${ }^{13} \mathrm{C}$ NMR signals was made for pure $20 \mathrm{E}$ in DMSO $\mathrm{d}_{6}(15.5 \mathrm{mg}$ of pure $20 \mathrm{E}$ in $0.5 \mathrm{ml}$ of water), excluding $\mathrm{OH}$ protons, which have two broad signals at 4.09 and $4.56 \mathrm{ppm}$, three broad superimposed signal at about $4.36 \mathrm{ppm}$, and a sharp signal at $4.63 \mathrm{ppm}$, which was designated as $\mathrm{OH}$ on carbon $\mathrm{C} 14$ due to the strong correlation of $\mathrm{HMBC}$ with carbon $\mathrm{C} 13$, and two weak correlations with carbon atoms $\mathrm{C} 14$ and $\mathrm{C} 15$. 
${ }^{1} \mathrm{H}$ and ${ }^{13} \mathrm{C}$ NMR chemical shifts in the free state $\left.\left(\delta_{0}, \text { DMSO-d }\right)_{6}\right)$ and in the composition of the complexes $\left(\delta, D_{2} O\right)$, ppm

\begin{tabular}{|c|c|c|c|}
\hline № & $20 \mathrm{E}$ in $\mathrm{CDCl}_{3}$ & $20 \mathrm{E}$ in $\mathrm{DMSO}-\mathrm{d}_{6}$ & $20 \mathrm{E}-\beta-\mathrm{CD}$ in $\mathrm{D}_{2} \mathrm{O}$ \\
\hline 1 & 2 & 3 & 4 \\
\hline \multicolumn{4}{|c|}{ 20E Signals } \\
\hline $\begin{array}{l}\mathrm{C} 1 \\
\mathrm{H} 1 \alpha \\
\mathrm{H} 1 \beta\end{array}$ & 37.96 & $\begin{array}{c}36.610 \\
1.263, \mathrm{dd}, 13.3,12.01 .598, \mathrm{dd}, 13.3,4.3\end{array}$ & $\begin{array}{c}35.499 \\
1.299, \mathrm{dd} \\
13.5,12.5 \\
1.788, \mathrm{dd}, 13.5,4.4\end{array}$ \\
\hline $\begin{array}{l}\mathrm{C} 2 \\
\mathrm{H} 2\end{array}$ & 68.03 & $\begin{array}{c}66.754 \\
3.604, \mathrm{ddd}, 11.9,4.3,3.1\end{array}$ & $\begin{array}{c}67.367 \\
3.880\end{array}$ \\
\hline $\begin{array}{l}\mathrm{C} 3 \\
\mathrm{H} 3\end{array}$ & 68.12 & $\begin{array}{c}66.570 \\
3.764, \sim q, 2.9\end{array}$ & $\begin{array}{c}67.128 \\
3.968, \sim q, 2.9\end{array}$ \\
\hline $\begin{array}{c}\mathrm{C} 4 \\
\mathrm{H} 4 \alpha \\
\mathrm{H} 4 \beta\end{array}$ & 32.41 & $\begin{array}{c}31.526 \\
1.473, \sim \mathrm{dt}, 13.7,3.8 \\
1.593, \mathrm{td}, 13.4,2.5\end{array}$ & $\begin{array}{c}31.154 \\
1.705, \text { br d } \\
1.627 \\
\end{array}$ \\
\hline $\begin{array}{l}\mathrm{C} 5 \\
\mathrm{H} 5\end{array}$ & 51.37 & $\begin{array}{c}50.072 \\
2.200, \mathrm{dd}, 13.1,4.2\end{array}$ & $\begin{array}{c}50.358 \\
2.270, \mathrm{dd},\end{array}$ \\
\hline & & & $12.6,5.0$ \\
\hline C6 & 203.43 & 202.620 & 208.101 \\
\hline $\begin{array}{l}\mathrm{C} 7 \\
\mathrm{H} 7\end{array}$ & 121.64 & $\begin{array}{c}120.432 \\
5.626, \mathrm{~d}, 2.6\end{array}$ & $\begin{array}{c}121.017 \\
5.891, \mathrm{~d}, 2.6\end{array}$ \\
\hline $\mathrm{C} 8$ & 166.03 & 165.187 & 168.242 \\
\hline $\begin{array}{l}\text { C9 } \\
\text { H9 }\end{array}$ & 34.43 & $\begin{array}{c}33.144 \\
3.007, \text { ddd, } 11.6,7.1,2.7\end{array}$ & $\begin{array}{c}33.831 \\
3.025, \text { ddd } \\
11.5,7.2,2.6\end{array}$ \\
\hline $\mathrm{C} 10$ & 38.64 & 37.601 & 38.161 \\
\hline $\begin{array}{l}\mathrm{C} 1 \\
\mathrm{H} 1 \alpha \\
\mathrm{H} 1 \beta\end{array}$ & 37.96 & $\begin{array}{c}36.610 \\
1.263, \mathrm{dd}, 13.3,12.01 .598, \mathrm{dd}, 13.3,4.3\end{array}$ & $\begin{array}{c}35.499 \\
1.299, \mathrm{dd}, \\
13.5,12.5 \\
1.788, \mathrm{dd}, 13.5,4.4\end{array}$ \\
\hline $\begin{array}{l}\mathrm{C} 2 \\
\mathrm{H} 2\end{array}$ & 68.03 & $\begin{array}{c}66.754 \\
3.604, \mathrm{ddd}, 11.9,4.3,3.1\end{array}$ & $\begin{array}{c}67.367 \\
3.880\end{array}$ \\
\hline $\begin{array}{l}\mathrm{C} 3 \\
\mathrm{H} 3 \\
\end{array}$ & 68.12 & $\begin{array}{c}66.570 \\
3.764, \sim q, 2.9\end{array}$ & $\begin{array}{c}67.128 \\
3.968, \sim q, 2.9\end{array}$ \\
\hline $\begin{array}{c}\mathrm{C} 4 \\
\mathrm{H} 4 \alpha \\
\mathrm{H} 4 \beta\end{array}$ & 32.41 & $\begin{array}{c}31.526 \\
1.473, \sim \mathrm{dt}, 13.7,3.8 \\
1.593, \mathrm{td}, 13.4,2.5\end{array}$ & $\begin{array}{c}31.154 \\
1.705, \text { br d } \\
1.627\end{array}$ \\
\hline $\begin{array}{l}\mathrm{C} 5 \\
\mathrm{H} 5\end{array}$ & 51.37 & $\begin{array}{c}50.072 \\
2.200, \mathrm{dd}, 13.1,4.2\end{array}$ & $\begin{array}{c}50.358 \\
2.270, \mathrm{dd}\end{array}$ \\
\hline & & & $12.6,5.0$ \\
\hline C6 & 203.43 & 202.620 & 208.101 \\
\hline $\begin{array}{l}\mathrm{C} 7 \\
\mathrm{H} 7\end{array}$ & 121.64 & $\begin{array}{c}120.432 \\
5.626, \mathrm{~d}, 2.6\end{array}$ & $\begin{array}{c}121.017 \\
5.891, \mathrm{~d}, 2.6\end{array}$ \\
\hline $\mathrm{C} 8$ & 166.03 & 165.187 & 168.242 \\
\hline $\begin{array}{l}\text { C9 } \\
\text { H9 }\end{array}$ & 34.43 & $\begin{array}{c}33.144 \\
3.007, \mathrm{ddd}, 11.6,7.1,2.7\end{array}$ & $\begin{array}{c}33.831 \\
3.025, \text { ddd } \\
11.5,7.2,2.6\end{array}$ \\
\hline $\mathrm{C} 10$ & 38.64 & 37.601 & 38.161 \\
\hline $\begin{array}{l}\text { C15 } \\
\text { H15a } \\
\text { H15P }\end{array}$ & 31.98 & $\begin{array}{c}30.303 \\
1.781, \sim \mathrm{td}, 11.6,5.5 \\
1.507, \sim \mathrm{q}, 9.6\end{array}$ & $\begin{array}{c}30.454 \\
1.979, \sim \mathrm{td} \\
10.4,6.2 \\
1.631, \sim \mathrm{dt}\end{array}$ \\
\hline $\begin{array}{l}\text { C16 } \\
\text { H16a } \\
\text { H16P }\end{array}$ & 21.47 & $\begin{array}{c}20.251 \\
1.871 \\
1.556\end{array}$ & $\begin{array}{c}20.493 \\
1.859, \sim \mathrm{q}, \\
11.1 \\
1.759, \sim \mathrm{dt}, 14.1,3.4\end{array}$ \\
\hline
\end{tabular}


Continuation of Table 2

\begin{tabular}{|c|c|c|c|}
\hline 1 & 2 & 3 & 4 \\
\hline $\begin{array}{l}\mathrm{C} 17 \\
\mathrm{H} 17\end{array}$ & 50.08 & $\begin{array}{c}48.676 \\
2.259, \sim \mathrm{t}, 9.0\end{array}$ & $\begin{array}{c}49.216 \\
2.250, \mathrm{dd}, 10.0,8.8\end{array}$ \\
\hline $\begin{array}{l}\text { C18 } \\
\text { H18 }\end{array}$ & 17.87 & $\begin{array}{c}17.114 \\
0.763, \mathrm{~s}\end{array}$ & $\begin{array}{c}17.268 \\
0.796, \mathrm{~s}\end{array}$ \\
\hline $\begin{array}{l}\text { C19 } \\
\text { H19 }\end{array}$ & 24.46 & $\begin{array}{c}23.841 \\
0.836, \mathrm{~s}\end{array}$ & $\begin{array}{l}23.352 \\
0.925, \mathrm{~s}\end{array}$ \\
\hline $\mathrm{C} 20$ & 76.82 & 75.682 & 77.599 \\
\hline $\begin{array}{l}\mathrm{C} 21 \\
\mathrm{H} 21\end{array}$ & 21.68 & $\begin{array}{l}20.959 \\
1.062, \mathrm{~s}\end{array}$ & $\begin{array}{c}20.095 \\
1.175\end{array}$ \\
\hline $\begin{array}{l}\mathrm{C} 22 \\
\mathrm{H} 22\end{array}$ & 77.52 & $\begin{array}{c}76.182 \\
3.115, \mathrm{dd}, 10.5,1.7\end{array}$ & $\begin{array}{c}77.010 \\
3.341, \mathrm{dd} \\
10.6,1.9\end{array}$ \\
\hline $\begin{array}{l}\mathrm{C} 23 \\
\mathrm{H} 23\end{array}$ & 27.45 & $\begin{array}{c}26.073 \\
1.475, \sim \operatorname{tdd}, 12.4,3.9,18 \\
1.111, \text { dddd, } 13.6,11.6,10.6,4.5\end{array}$ & $\begin{array}{l}26.018 \\
1.535 \\
1.237\end{array}$ \\
\hline $\begin{array}{l}\mathrm{C} 24 \\
\mathrm{H} 24\end{array}$ & 42.62 & $\begin{array}{c}41.377 \\
1.645, \sim \mathrm{td}, 12.8,5.0 \\
1.253, \mathrm{ddd}, 13.1,11.6,4.3\end{array}$ & $\begin{array}{c}40.818 \\
1.651, \text { ddd } \\
13.2,10.6,5.3 \\
1.417, \text { ddd, } \\
13.2,11.1,4.3\end{array}$ \\
\hline $\mathrm{C} 25$ & 69.52 & 68.673 & 71.265 \\
\hline $\begin{array}{l}\mathrm{C} 26 \\
\mathrm{H} 26\end{array}$ & 29.99 & $\begin{array}{l}29.972 \\
1.077, \mathrm{~s}\end{array}$ & $\begin{array}{l}28.052 \\
1.138, \mathrm{~s}\end{array}$ \\
\hline $\begin{array}{l}\mathrm{C} 27 \\
\mathrm{H} 27\end{array}$ & 30.09 & $\begin{array}{l}28.990 \\
1.052, \mathrm{~s}\end{array}$ & $\begin{array}{l}27.949 \\
1.135, \mathrm{~s}\end{array}$ \\
\hline \multicolumn{4}{|c|}{$\beta$-cyclodextrin signals } \\
\hline $\begin{array}{l}\mathrm{C} 1 \\
\mathrm{H} 1\end{array}$ & - & - & $\begin{array}{c}102.238 \\
4.991, \mathrm{~d}, 3.8\end{array}$ \\
\hline $\begin{array}{l}\mathrm{C} 2 \\
\mathrm{H} 2\end{array}$ & - & - & $\begin{array}{l}72.161 \\
3.575, \mathrm{dd}, 9.9 \\
3.7\end{array}$ \\
\hline $\begin{array}{l}\text { C3 } \\
\text { H3 }\end{array}$ & - & - & $\begin{array}{c}73.248 \\
3.885, \mathrm{dd}, 9.9 \\
9.0\end{array}$ \\
\hline $\begin{array}{l}\mathrm{C} 4 \\
\mathrm{H} 4\end{array}$ & - & - & $\begin{array}{c}81.466 \\
3.512, \sim \mathrm{t}, 9.3\end{array}$ \\
\hline $\begin{array}{l}\mathrm{C} 5 \\
\mathrm{H} 5\end{array}$ & - & - & $\begin{array}{l}71.929 \\
3.781\end{array}$ \\
\hline $\begin{array}{c}\mathrm{C} 6 \\
\mathrm{H} 6(2 \mathrm{H})\end{array}$ & - & - & $\begin{array}{c}60.282 \\
\sim 3.79 \\
\end{array}$ \\
\hline
\end{tabular}

The formation of an internal complex with ecdysterone is assumed. The study of the integral intensities of the signals of the guest and host molecules allows us to conclude that the stoichiometric ratio is 1:1. To identify the fragment of the $20 \mathrm{E}$ molecule located in the inner sphere of the $\mathrm{CD}$, the changes in the values of the chemical shift were studied. The overlapping of ${ }^{1} \mathrm{H}$ signals of the substrate significantly complicates the analysis of NMR data; however, one can assume the formation of a supramolecular ensemble according to Figure 2.

Wide signal of residual water at $3.30 \mathrm{ppm}$ has an intensity of $0.17 \mathrm{H}$. Other signals and most of their characteristics are shown in Table 2. JHH values, cross-peak intensities in HMBC and ROESY were used to establish the geometry of the 20E steroid part (aliphatic part from C23 rotates freely).

The signal of the ${ }^{1} \mathrm{H} \beta$-CD proton was chosen as an internal reference, since this proton is located outside the $\beta$-CD cavity and therefore should be least affected by complexation. The changes $\left(\delta 27{ }^{\circ} \mathrm{C}-\delta 1{ }^{\circ} \mathrm{C}\right)$ on the signals $\mathrm{H} 1, \mathrm{H} 2, \mathrm{H} 3, \mathrm{H} 4$, and $\mathrm{H} 5$ of the $\mathrm{CD}$ part were $0,+4,-12,-7$, and $-8 \mathrm{ppb}$, respectively, i.e. a large change was observed on the internal H3 $\beta$-CD. Similar changes were observed on $\mathrm{H} 1 \alpha(-2), \mathrm{H} 2(+38)$, H3 (+18), H5 (-13), H7 (-8), H9 (+4), H17 (+3), H18 (-9), H19 (-19), H21 (-6), H22 (-3), H23 (-8), H24 ' $(0)$, H26 ( -2$), \mathrm{H} 27(-4)$ signals of 20E part; other signals were not observed due to overlap. 
In general, an unambiguous conclusion about the geometry of the complex can be made by interpreting the intermolecular interactions in the ROESY spectra.

As expected, final ROEs between $20 \mathrm{E}$ and $\mathrm{H} 1, \mathrm{H} 2$, or $\mathrm{H} 4$ signals (outer hydrogen atoms) $\beta$-CD were not observed in all samples. This suggests that $20 \mathrm{E}$ forms a complex inside the $\beta$-CD cavity or that the concentration of other complexes was not detected under the studied conditions. This indicates that all the observed intermolecular ROEs are associated with the fact that 20E is located more or less inside the $\beta$-CD cavity. Despite a number of signal overlaps, it was possible to establish whether the aliphatic or steroid portion of $20 \mathrm{E}$ is in the $\beta-\mathrm{CD}$ at $\mathrm{O} 6$ ( $\mathrm{ROE}$ to $\mathrm{H} 5 / \mathrm{H} 6$ ) or $\mathrm{O} 3$ (ROE to $\mathrm{H} 3$ ), based on the unambiguous presence/absence of ROE on the recognizable signals. H5 and both H6 $\beta$-CD signals overlap; however, since they are within the $\beta$-CD molecule, this is not a serious problem. The H3 $\beta$-CD signal overlaps with the H2 20E signals, thus only ROE cross-peaks that are not observed in pure $20 \mathrm{E}$ can be attributed to H3 $\beta$-CD.

These signals were separated at $1{ }^{\circ} \mathrm{C}$, allowing for a more unambiguous interpretation.

We identified a strong ROE H5 / H6 $\beta$-CD for the 20E H23, H23', H24', H26/H27 signals, as well as the ROE H3 $\beta$-CD for the 20E H17, H18, H19, and H22 signals. This suggests that the 20E aliphatic portion is inserted deep into the $\beta$-CD through the O3 rim. Surprisingly, there are also weak ROE H5 / H6 $\beta$-CD for $20 \mathrm{E} \mathrm{H} 18, \mathrm{H} 21$ and $\mathrm{H} 22$ signals and $\mathrm{H} 3 \beta-\mathrm{CD}$ on $20 \mathrm{E} \mathrm{H} 26$ and $\mathrm{H} 27$ signals. This can be explained by simultaneous complexation through the $\mathrm{O} 6$ rim or complex formation through the $\mathrm{O} 3 \mathrm{rim}$, however, with $\beta-\mathrm{CD}$ has at least one inverted sugar unit. ROE H3 $\beta$-CD for $20 \mathrm{E}$ signals $\mathrm{H} 1 \beta, \mathrm{H} 4 \alpha, \mathrm{H} 4 \beta, \mathrm{H} 5$ and $\mathrm{H} 19$ suggests ring A complexation, but no ROE for $\mathrm{H} 1 \alpha$. This can be understood as hindering $\mathrm{H} 1 \alpha$ from constant ROE by the nearby $\mathrm{H} 19$ methyl and $\mathrm{OH}$ group (s).

Pure 20E has a strong ROE between $\mathrm{H} 9$ and $\mathrm{H} 2$, and no ROE between $\mathrm{H} 9$ and $\mathrm{H} 3$, which is consistent with the molecular model where the $\mathrm{H} 9-\mathrm{H} 2$ distance is $0.18 \mathrm{~nm}$ and the $\mathrm{H} 9-\mathrm{H} 3$ distance is $0.38 \mathrm{~nm}$. The change in the conformation of ring A can also be supported by the largest changes in chemical shifts on this ring with changes in temperature. Unfortunately, we were unable to identify significant changes in HMBC to reveal more details about the geometry changes.

Based on the obtained NMR spectroscopy data, which accurately describes the formation of a hydrophilic complex of ecdysterone entry into the cavity of the $\beta$-cyclodextrin molecule, thereby relying on the obtained result, we can confidently formulate the final data, which undoubtedly represent the characteristics of the supramolecular inclusion complex. Thus, the study of the target complex in $\mathrm{D}_{2} \mathrm{O}$ yielded a result in which the main proton signal of $\mathrm{H}-7$ was revealed, that is precise characteristic for compounds of the cholestanic structure, indicating that this substance is already capable of dissolving in water, and thereby makes it possible to conduct experiments on the study of hydrophilicity.

\section{Conclusions}

This work proposes the most optimal method for obtaining the inclusion complex of 20-hydroxyecdysone, isolated from the industrially significant plant Silene wolgensis with $\beta$-CD in a 1:1 ratio (substrateclathrate). Based on the results obtained on preparative chromatography of the target product and the development of its chemically modified form, an optimal technological scheme has been proposed, in which the main stages of the production of a water-soluble substance are established. On the basis of the primary data on physicochemical constants, the criteria for standardization of the finished medicinal substance were established. The fine structure of the $20 \mathrm{E}$ inclusion complex with $\beta-\mathrm{CD}$ was fully confirmed by the data of twodimensional correlation of the ${ }^{1} \mathrm{H}$ and ${ }^{13} \mathrm{C}$ NMR spectra, thus, studying the main structural features of the supramolecular-clathrate inclusion complex. For the first time, on the basis of ecdysterone, a water-soluble drug substance of ecdysterone with $\beta$-cyclodextrin was obtained and its fine structure was confirmed. For the first time, a pilot industrial regulation for the isolation of ecdysterone from the Silene wolgensis and the production of a water-soluble form on its basis was developed. The developed method for obtaining a watersoluble form of ecdysterone is of great interest for the pharmaceutical industry as the basis for many actoprotective phytopreparations.

\section{Acknowledgments}

This work was financially supported by the Science Committee, a grant from the Ministry of Education and Science of the Republic of Kazakhstan (Project No. AP09260549). 


\title{
References
}

1 Butenandt A. Crystallization of insectmoulting hormone / A. Butenandt, P. Karlson // Naturforsch. — 1954. — Vol. 9. — P. 389-391.

2 Nakanishi K. Insect hormones. The structure of ponasterone A, an insectmoulding hormone from the leaves of Podocarpus nakaii Hay / K. Nakanishi, A. Butenandt, M. Koreeda, S. Sasaki // J. Chem. Soc. Chem. Commun. — 1996. — Vol. 24. — P. $915-$ 917.

3 Ахрем А.А. Экдистероиды: Химия и биологическая активность / А.А. Ахрем, Н.В. Ковганко. — Минск: Наука и техника, 1989. - $327 \mathrm{c.}$

4 Тулеуов Б.И. Стероидные соединения растений и лекарственные препараты на их основе. Поиск, химическая модификация и практические аспекты применения / Б.И. Тулеуов. — Караганда: Гласир, 2009. — 208 с.

5 Рамазонов Н.Ш. Химия, биология и технология получения фитоэкдистероидов / Н.Ш. Рамазонов, И.Д. Бобаев, В.Н. Сыров, Ш.Ш. Сагдуллаев, А.У. Маматханов. - Ташкент: Fan va texnologiya, 2016. — 260 с.

6 Сейлханов Т.М. ЯМР-спектроскопия циклодекстриновых комплексов включения / Т.М. Сейлханов. — Кокшетау: КГУ им. Ш. Уалиханова, 2015. - 155 с.

7 Бобров Е.Г. Флора СССР / Е.Г. Бобров, С.К. Черепанов. - М.: АН СССР, 1963. - С. 308.

8 Бондаренко О.Н. Род Silene L. - Смолевка // Определитель растений Средней Азии / О.Н. Бондаренко. — Ташкент: Фан, 1971. - С. 253-277.

9 Павлов Н.В. Флора Казахстана / Н.В. Павлов. - Алма-Ата: Наука КазССР, 1966. — 366 с.

10 Тулеуов Б.И. Технология фитостеоидных препаратов / Б.И. Тулеуов. — Караганда: Гласир, 2017. — 112 с.

11 Лабораторный регламент на выделение полиоксистероидов из сырья Silene wolgensis (Hornem.) Bess. и получение водорастворимых форм на их основе // ЛР-№ 40761819-06-20., 2020 г.

12 Temirgaziyev B.S. Bioavailability and structural study of 20-hydroxyecdysone complexes with cyclodextrins / B.S. Temirgaziyev, K. Kucakova, Ye.A. Baizhigit, M. Jurasek et al. // Steroids. - 2019. - Vol. 147. - P.37-41. https://doi.org/10.1016/j.steroids.2018.11.007

13 Кожанова А.М. Синтез, ЯМР-спектроскопическое исследование $\alpha$-, $\beta$ - и $\gamma$-циклодекстриновых комплексов включения 2-дезоксиэкдизона и их противовоспалительная активность / А.М. Кожанова, Б.И. Тулеуов, П.К. Кудабаева, Б.С. Темиргазиев, Т.М. Сейлханов, Р.Б. Сейдахметова, Л.К. Салькеева, С.М. Адекенов // Макрогетероциклы. — 2020. № 3. - C. 292-297. DOI: 10.6060/mhc200602t

14 Tuleuov B.I. Supramolecular Complexes of 20-hydroxyecdysone-3-acetate with $\beta$-Cyclodextrin and Its Biological Activity/ B.I. Tuleuov, B.S. Temirgaziev, A.M. Kozhanova, R.B. Seidakhmetova, K.M. Turdybekov, T.M. Seilkhanov, O.T. Seilkhanov, P. Drasar, S.M. Adekenov // Russian Journal of General Chemistry. - 2020. - Vol. 90. — P. $2258-2263$. DOI: $10.1134 / \mathrm{S} 1070363220120075$

15 Kozhanova A.M. Technology of Obtaining a new water-soluble form of ecdysterone-substance from Silene wolgensis / A.M. Kozhanova, B.S. Temirgaziyev, Ye.V. Minayeva, B.I. Tuleuov, A.A. Rakhatayeva, P. Drasar, S.M. Adekenov // XIII International Symposium on the Chemistry of Natural Compounds (ISCNC 2019). October 16-19, 2019. — Shanghai. — P. 125.

16 Kozhanova A.M. Synthesis, Structure and Bioactivity of a new water-soluble 20-Hydroxyecdysone Derivative / A.M. Kozhanova, B.S. Temirgaziyev, Ye.V. Minayeva, T.M. Seilkhanov, R.B. Seidakhmetova, B.I. Tuleuov, S.M. Adekenov // XIII International Symposium on the Chemistry of Natural Compounds (ISCNC 2019). October 16-19, 2019. — Shanghai. — P. 126.

17 Государственная фармакопея Республики Казахстан. - Алматы: Изд. дом “Жибек жолы”, 2014. — 872 с.

А.М. Қожанова, Б.С. Темірғазиев, Ә. Жанарбек, Б.И. Төлеуов, Т.М. Сейілханов, С.М. Әдекенов

\section{Экдистеронның гидрофильді туындысының синтезі және оның негізінде суда еритін түрін алу}

\begin{abstract}
Мақалада Silene wolgensis (Hornem.) Bess. ex. Spreng (волга сылдыршөбі) дәрілік өсімдік шикізатынан экдистерон субстанциясын бөліп алу бойынша мәліметтер келтірілген. Алғаш рет фитоэкдистероидтардың асқын концентраторы волга сылдыршөбінің жерүсті бөлігінен экдистерон алу әдісінің оңтайландырылуы жүргізілді және экдистерон мен оның негізіндегі инкапсулденген суда еритін түрін алудың тәжірибелік-өнеркәсіптік регламенті жасалынды. Субстрат молекуласы мен клатраттың өзара әрекеттесуінен суда және басқа полярлы еріткіштерде ери алатын зат түзілетіні, сол арқылы негізгі гидрофобты препараттың биожетімділігі мәселесі шешілетіні анықталды. Экдистерон субстанциясы және оның $\beta$-циклодекстринмен инкапсулденген суда еритін түрін алу әдісі Қарағанды фармацевтикалық зауытында өндіріске ендірілді. Субстраттар мен рецепторлар протондарының химиялық жылжуларының өзгерістерін ЯМР-зерттеулер кезінде, экдистеронның $\beta$-циклодекстринмен 1:1 стехиометриялық құрамдағы молекулаүстілік ену кешендерін түзе отырып әрекеттесетіні
\end{abstract}


табылды. Экдистеронның $\beta$-циклодекстринмен инкапсулденген кешенінің, фитоэкдистеронның өзіне қарағанда суда ерігіштігінің 100 есе артатыны анықталды.

Кілт сөздер: экдистерон, бөліп алуды оңтайландыру, Silene wolgensis, $\beta$-циклодекстрин, инкапсулдеу, суда ерігішті.

\author{
А.М. Кожанова, Б.С. Темиргазиев, А. Жанарбек, \\ Б.И. Тулеуов, Т.М. Сейлханов, С.М. Адекенов \\ Синтез гидрофильного производного экдистерона \\ и разработка водорастворимой формы на его основе
}

\begin{abstract}
В статье представлены материалы по выделению экдистерона субстанции из лекарственного растительного сырья Silene wolgensis (Hornem.) Bess. ex. Spreng (смолевка волжская). Впервые проведена оптимизация способа получения экдистерона из надземной части сверхконцентратора фитоэкдистероидов смолевки волжской и разработан опытно-промышленный регламент выделения экдистерона и инкапсулированной водорастворимой формы на его основе. Найдено, что при взаимодействии молекулы субстрата и клатрата образуется вещество, способное растворяться в воде и других более полярных растворителях, тем самым решая проблему биодоступности основного гидрофобного лекарственного соединения. Разработанный способ получения экдистерона субстанции и его инкапсулированной с $\beta$-циклодекстрином водорастворимой формы внедрен в производство на Карагандинском фармацевтическом заводе. При ЯМР-изучении изменений химических сдвигов протонов субстратов и рецепторов найдено, что экдистерон взаимодействует с $\beta$-циклодекстрином с образованием надмолекулярных комплексов включения стехиометрического состава 1:1.
\end{abstract}

Ключевые слова: экдистерон, оптимизация выделения, Silene wolgensis, $\beta$-циклодекстрин, инкапсулирование, водорастворимость, ЯМР-спектроскопия, супрамолекулярные комплексы.

\title{
References
}

1 Butenandt, A. (1954). Crystallization of insectmoulting hormone. Naturforsch, 9, 389-391.

2 Nakanishi, K., Koreeda, M., Sasaki, S., Chang, M.L., \& Hsu, H.Y. (1996). Insect hormones. The structure of ponasterone A, an insectmoulding hormone from the leaves of Podocarpus nakaii Hay. J. Chem. Soc. Chem. Commun., 24, $915-917$.

3 Akhrem, A.A. \& Kovganko, N.V. (1989). Ekdisteroidy: khimiia i biologicheskaia aktivnost [Ecdysteroids: chemistry and biological activity], Minsk: Nauka i tekhnika [in Russian].

4 Tuleuov, B.I. (2009). Steroidnye soedineniia rastenii i lekarstvennye preparaty na ikh osnove. Poisk, khimicheskaia modifikatsiia i prakticheskie aspekty primeneniia [Steroid compounds of plants and drugs based on them. Search, chemical modification and practical aspects of application]. Karaganda: Glasir [in Russian].

5 Ramazonov, N.Sh., Bobayev, I.D., Syrov, V.N., Sagdullayev, Sh.Sh., Mamatkhanov, A.U. (2016). Khimiia, biologiia $i$ tekhnologiia polucheniia fitoekdisteroidov [Chemistry, biology and technology of phytoecdysteroid production]. Tashkent: Fan va texnologiya [in Russian]

6 Seylkhanov, T.M. (2015). YAMR-spektroskopiia tsiklodekstrinovykh kompleksov vklyucheniya [NMR spectroscopy of cyclodextrin inclusion complexes]. Kokshetau: KGU imeni Sh. Ualikhanova [in Russian].

7 Bobrov, E.G., Cherepanov, S.K. (1963). Flora SSSR [Flora of the USSR]. Moscow: Akademiia nauk SSSR [in Russian].

8 Bondarenko, O.N. (1971). Rod Silene L. - Smolevka [Genus Silene L. - Smolevka]. Opredelitel rastenii Srednei Azii Keys to plants of Central Asia. Tashkent: Fan [in Russian].

9 Pavlov, N.V (1966). Flora Kazakhstana [Flora of Kazakhstan]. Alma-Ata: Nauka KazSSR [in Russian]. sian].

10 Tuleuov, B.I. (2017). Tekhnologiia fitosteroidnykh preparatov [Phytosteroid drug technology]. Karaganda: Glasir [in Rus-

11 Laboratory regulations for the isolation of polyoxysteroids from raw materials Silene wolgensis (Hornem.) Bess. and obtaining water-soluble forms on their basis. LR-№ 40761819-06-20. - 2020.

12 Temirgaziyev, B.S., Kucakova, K., Baizhigit, Ye.A., Jurasek, M., Dzubak, P., \& Hajduch, M., et al. (2019). Bioavailability and structural study of 20-hydroxyecdysone complexes with cyclodextrins. Steroids, 147, 37-41. https://doi.org/10.1016/j.steroids.2018.11.007

13 Kozhanova, A.M., Tuleuov, B.I., Kudabaeva, P.K., Temirgaziev, B.S., Seikhanov, T.M., \& Seidakhmetova, R.B. et al. (2020). Sintez, IaMR-spektroskopicheskoe issledovanie $\alpha$-, $\beta$ - i $\gamma$-tsiklodekstrinovykh kompleksov vkliucheniia 2-dezoksiekdizona $i$ ikh protivovospalitelnaia aktivnost [Synthesis, NMR Spectroscopic Study of $\alpha-\beta$ - and $\gamma$-Cyclodextrin Inclusion Complexes of 2-Deoxyecdysone and Their Anti-inflammatory Activity]. Makrogeterotsikly - Macroheterocycles, 13, 292-297. DOI: $10.6060 / \mathrm{mhc} 200602 \mathrm{t}$ 
14 Tuleuov, B.I., Temirgaziev, B.S., Kozhanova, A.M., Seidakhmetova, R.B., Turdybekov, K.M., \& Seilkhanov, T.M. (2020). Supramolecular Complexes of 20-hydroxyecdysone-3-acetate with $\beta$-Cyclodextrin and Its Biological Activity. Russian Journal of General Chemistry, 90, 12, 2258-2263. DOI: 10.1134/S1070363220120075

15 Kozhanova, A.M., Temirgaziyev, B.S., Minayeva, Ye.V., Tuleuov, B.I., Rakhatayeva, A.A., Drasar, P., \& Adekenov, S.M. (2019). Technology of obtaining a new water-soluble form of ecdysterone-substance from Silene wolgensis. Proceedings from XIII International Symposium on the Chemistry of Natural Compounds (16-19 October 2019 year). (p. 125). Shanghai: ISCNC 2019.

16 Kozhanova, A.M., Temirgaziyev, B.S., Minayeva, Ye.V., Seilkhanov, T.M., Seidakhmetova, R.B., Tuleuov, B.I., \& Adekenov, S.M. (2019). Synthesis, Structure and Bioactivity of a new water-soluble 20-Hydroxyecdysone Derivative. Proceedings from XIII International Symposium on the Chemistry of Natural Compounds (16-19 October 2019 year). (p. 126). Shanghai: ISCNC 2019.

17 Gosudarstvennaia farmakopeia Respubliki Kazakhstan (3th ed.) (2014). Almaty: Izdatelskii dom "Zhibek zholy" [in Russian].

\section{Information about authors}

Kozhanova Aizhan Mukhametkalievna - Master's degree of Technical Sciences; Junior Researcher of the Laboratory of Chemistry of Steroid Compounds of JSC "International Research and Production Holding "Phytochemistry", Gazaliev street 4, 100009, Karaganda, Kazakhstan; e-mail: alhss@mail.ru; https://orcid.org/0000-0002-1048-9749

Temirgaziev Bakhtiyar Serikovich - Master's degree of Technical Sciences; Researcher of the Laboratory of Chemistry of Steroid Compounds of JSC "International Research and Production Holding "Phytochemistry", Gazaliev street 4, 100009, Karaganda, Kazakhstan; e-mail: alhss@ mail.ru; e-mail: b_a_h_a1990@mail.ru; https://orcid.org/0000-0001-6994-3478

Zhanarbek Alima Zhanarbekkyzy - Engineer of the Laboratory of chemistry of steroid compounds of JSC "International Research and Production Holding "Phytochemistry", Gazaliev street 4, 100009, Karaganda, Kazakhstan; e-mail: zhalima17@mail.ru; https://orcid.org/0000-0003-3955-0213

Tuleuov Borash Iglikovich - Doctor of Chemical Sciences, Professor, Academician of the National Academy of Sciences of the Republic of Kazakhstan; Head of the Laboratory of Chemistry of steroid Compounds of JSC "International Research and Production Holding "Phytochemistry" Gazaliev street 4, 100009, Karaganda, Kazakhstan; e-mail: tulbor@mail.ru; https://orcid.org/0000-0002-7592-9768

Seilkhanov Tulegen Muratovich - Candidate of Chemical Sciences, Professor, Head of the Laboratory of engineering profile of NMR Spectroscopy of the Sh. Ualikhanov Kokshetau University, Abay street 76, 020000, Kokshetau, Kazakhstan; e-mail: tseilkhanov@mail.ru; https://orcid.org/0000-0003-0079-475

Adekenov Sergazy Mynzhasarovich - Doctor of Chemical Sciences, Professor, Academician of the National Academy of Sciences of the Republic of Kazakhstan; General Director of JSC "International Research and Production Holding "Phytochemistry", Gazaliev street 4, 100009, Karaganda, Kazakhstan; e-mail: arglabin@phyto.kz; https://orcid.org/0000-0001-7588-6174 